\title{
Sulfated tin oxides: a suitable reagent for synthesis of 2,4-diphenyl-4,6,7,8-tetrahydrochromen-5-one
}

\author{
Swapnil R. Sarda, ${ }^{\text {a }}$ Vijay A. Puri, ${ }^{\text {b Ambadas B. Rode, }}$, Tulshiram N. Dalawe, \\ Wamanrao N. Jadhav, ${ }^{b}$ and Rajendra P. Pawar ${ }^{\mathrm{b} *}$ \\ ${ }^{a}$ Department Of Chemistry,J.E.S. College, Jalna-431203, India \\ ${ }^{b}$ Organic Chemistry Synthesis Laboratory, Dnyanopasak College, Parbhani-431401, India \\ E-mail:rppawar@yahoo.com
}

\begin{abstract}
$\alpha-\beta$-Unsaturated carbonyl compounds on heating with1,3-cyclohexanedione in the presence of sulfated tin oxide catalyst offers corresponding 2,4-diphenyl-4,6,7,8-tetrahydro chromen-5-one in excellent yield. The catalyst can be recovered by simple filtration and recycled for several times in subsequent reactions without change in its efficiency.
\end{abstract}

Keywords: $\alpha, \beta$-Unsaturated carbonyl compounds, 1,3-cyclohexanedione, sulfated tin oxide, 2,4diphenyl-4,6,7,8-tetrahydro chromen-5-one

\section{Introduction}

2,4-Diphenyl-4,6,7,8-tetrahydrochromen-5-one is an important class of organic compounds due to their wide range of biological activities. They possess antijuvenile hormone activity, ${ }^{1}$ antianaphylactic activity in trachea, ${ }^{2}$ antiallergic, ${ }^{3,4}$ anti-inflammatory, ${ }^{5}$ anticancer activity ${ }^{6}$ and are also helpful in diabetic complications. ${ }^{7}$

Several methods have been reported for the synthesis of chromen-5-one. One of the conventional method is the condensation of $\alpha-\beta$-unsaturated carbonyl compounds (chalcones) with 1,3-cyclohexanedione. The process is two steps in which the Michael addition of cyclic 1,3 diketone to chalcones followed by cyclization of resultant diketo intermediate, ${ }^{8,9}$ in acetic acid and phosphorus pentoxide at $120{ }^{\circ} \mathrm{C},{ }^{10}$ in methanol and triethylamine at reflux temperature, ${ }^{11}$ in toluene and n-heptane using anhydrous $\mathrm{ZnCl}_{2},{ }^{12}$ in benzene n-heptane and anhydrous $\mathrm{ZnCl}_{2}$ at reflux for 28-30 hours. ${ }^{13}$ All the above-discussed methods have several limitations such as longer reaction time, strong acidic conditions and low yield. Consequently there was a scope for further work on this reaction under mild reaction conditions, simple work up, and better yield. It is achieved using sulfated tin oxide $\left(\mathrm{SO}_{4}{ }^{-2} / \mathrm{SnO}_{2}\right)$ as solid super acid catalyst (STO). 
Herein we wish to report an efficient and mild protocol for the synthesis of 2,4-diphenyl4,6,7,8-tetrahydro chromen-5-one using sulfated tin oxide as solid super acid catalyst.

\section{Results and Discussion}

In a model reaction $\alpha, \beta$-unsaturated carbonyl compounds (1), 1,3-cyclohexanedione (2) and sulfated tin oxide catalyst in dimethyl formamide (DMF) was stirred at $90^{\circ} \mathrm{C}$ for a suitable time.

After completion of the reaction, solid catalyst was separated by filtration and the usual work up offered the pure chromen-5-one (3). The separated solid catalyst was washed with ethyl acetate and dried at $110{ }^{\circ} \mathrm{C}$ for 1 hour. The activated catalyst is recycled and reused for several times in subsequent reactions without change in its efficiency.

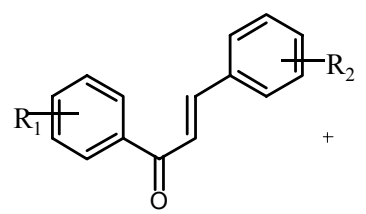

1

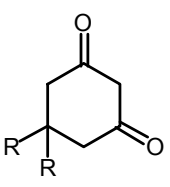

2

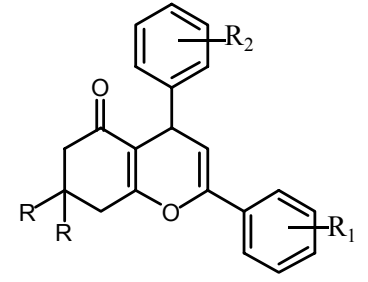

3

\section{Scheme 1}

Recently sulfated metal oxides have been used as a catalyst in several organic transformations ${ }^{14}$ due to its high efficiency, non-pollutant and non-corrosive aspects, lower cost and greater stability. It has the strongest acidity on the surface. It can be easily recovered from the reaction mixture by simple filtration and re-used after activation. Thus the sulfated tin oxide $\left(\mathrm{SO}_{4}{ }^{-2} / \mathrm{SnO}_{2}\right)$ is superior than other known acids. ${ }^{15}$ Sulfated tin oxide has a higher surface area as compare to aluminosilicates or zeolites. Thus it is widely used in hydro cracking of paraffin's, dehydration of alcohol, esterification, alkylation's of olefins, photochemical catalysis and protection of aldehyde, ketones and alcohols ${ }^{19}$ and olefin polymerization. ${ }^{20}$

Synthesis of chromen-5-one derivatives using sulfated tin oxide super acid catalyst is rapid and ecofriendly (Table 1). Most of the reactions were completed within 7-8 hours affording 90$95 \%$ yield of the product. By contrast, the reported methods required much longer reaction time and strong acidic conditions. The sulfated tin oxide-DMF system is found to be more suitable because of shorter reaction time and easy workup. But using other organic solvent systems it required longer reaction times (Table 2). In absence of catalyst, the reaction took a longer time (30-38 hrs.). The best result was obtained using $5 \mathrm{~mol} \%$ of sulfated tin oxide in solvent dimethyl formamide at $90^{\circ} \mathrm{C}$. Greater amounts of the catalyst did not improve the yield. Insolubility of catalyst sulfated tin oxide in different organic solvents provided an easy method for its separation from the product. The catalyst was separated by filtration and reused after activations with only a 
gradual decrease in its efficiency (for example the product (3a) was obtained in $94 \%, 90 \%, 88 \%$ yields over three runs (Table 3 ).

Table 1. Synthesis of 2,4-diphenyl-4,6,7,8-tetrahydro chromen-5-one catalyzed by sulfated metal oxides

\begin{tabular}{|c|c|c|c|c|c|c|}
\hline Entry & $\begin{array}{c}\alpha-\beta \text {-unsaturated } \\
\text { ketone } \\
(1)\end{array}$ & $\begin{array}{c}1,3- \\
\text { Diketones } \\
(2)\end{array}$ & $\begin{array}{c}\text { Products } \\
\text { (3) }\end{array}$ & $\begin{array}{l}\text { Time } \\
\text { (h) }\end{array}$ & $\begin{array}{c}\text { M.P. }\left({ }^{0} \mathrm{C}\right) \\
\text { (Reported) }\end{array}$ & $\begin{array}{l}\text { Yield } \\
(\%)^{a}\end{array}$ \\
\hline $\mathrm{a}$ & & & & 7 & $\begin{array}{c}142-143 \\
(140-141)^{10}\end{array}$ & 92 \\
\hline $\mathrm{b}$ & & & & 7.5 & $\begin{array}{c}172-174 \\
(175-176)^{12}\end{array}$ & 90 \\
\hline $\mathrm{c}$ & & & & 7 & $\begin{array}{c}164-165 \\
(162-163)^{12}\end{array}$ & 85 \\
\hline $\mathrm{d}$ & & & & 7 & $\begin{array}{c}212-214 \\
(213-214)^{13}\end{array}$ & 90 \\
\hline $\mathrm{e}$ & & & & 7.5 & $\begin{array}{c}189-192 \\
(188-190)^{12}\end{array}$ & 80 \\
\hline $\mathrm{f}$ & & & & 7 & $\begin{array}{c}130-131 \\
(131-132)^{12}\end{array}$ & 85 \\
\hline $\mathrm{g}$ & & & & 7.5 & $\begin{array}{c}195-198 \\
(192-193)^{13}\end{array}$ & 80 \\
\hline
\end{tabular}




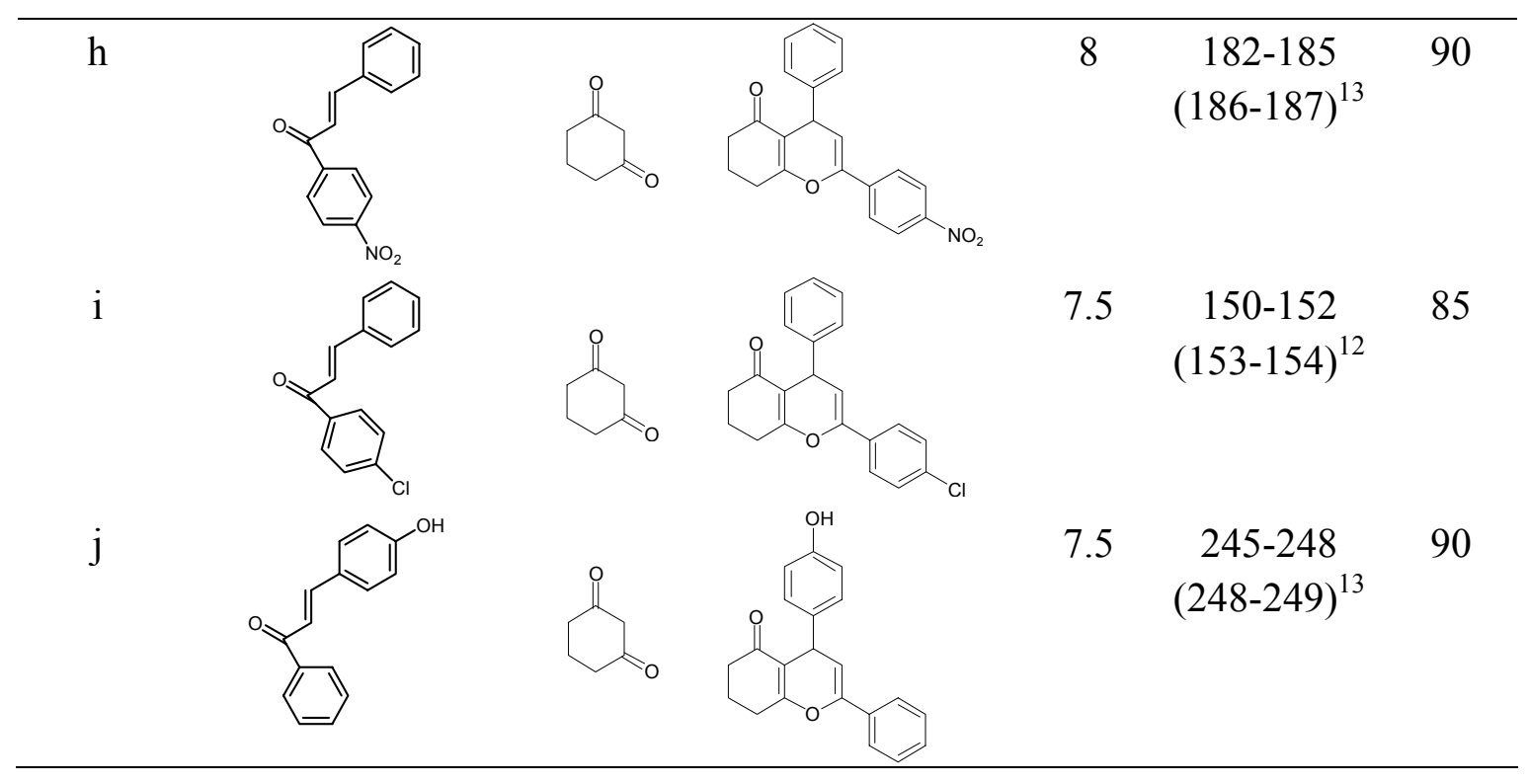

${ }^{\mathrm{a}}$ Isolated and unoptimized yield.

Table 2. Synthesis of 7,7, dimethyl-2,4-diphenyl-4,6,7,8-tetrahydro chromen-5-one(3a)catalyzed by sulfated tin oxides in various solvents ${ }^{\mathrm{a}}$

\begin{tabular}{ccccc}
\hline Entry & Solvent & Temp. ${ }^{0} \mathrm{C}$ & Time (hr) & Yield $^{\mathrm{b}}(\%)$ \\
\hline 1 & Toluene & Reflux & 12 & 70 \\
2 & $\mathrm{CH}_{3} \mathrm{CN}$ & Reflux & 14 & 75 \\
3 & $\mathrm{C}_{2} \mathrm{H}_{5} \mathrm{OH}$ & Reflux & 13 & 70 \\
4 & $\mathrm{CH}_{3} \mathrm{OH}$ & Reflux & 14 & 65 \\
5 & $\mathrm{DMF}$ & $\mathrm{RT}$ & 38 & No reaction \\
6 & $\mathrm{DMF}$ & $120^{\circ} \mathrm{C}$ & 4.5 & 90 \\
7 & $\mathrm{DMF}$ & $90^{0} \mathrm{C}$ & 07 & 92 \\
\hline
\end{tabular}

${ }^{\mathrm{a}}$ Reaction conditions:- 5,5-dimethyl-cyclohexane-1,3,dione (1 mmol), 1,3-diphenyl-propenone (1 mmol), sulfated tin oxides ( $5 \mathrm{~mol} \%)$. ${ }^{\mathrm{b}}$ Isolated and unoptimized yield.

Table 3. Recovery of sulfated tin oxide (STO) catalyst in the synthesis of 2,4-diphenyl-4,6,7,8tetrahydro chromen-5-one

\begin{tabular}{|c|c|c|c|c|c|c|}
\hline \multirow[b]{2}{*}{ Entry } & \multirow{2}{*}{$\begin{array}{c}\alpha \text { - } \beta \text {-unsaturated } \\
\text { ketone (1) }\end{array}$} & \multirow{2}{*}{$\begin{array}{c}1,3- \\
\text { Diketone } \\
(2)\end{array}$} & \multirow{2}{*}{$\begin{array}{c}\text { Products } \\
\text { (3) }\end{array}$} & \multicolumn{3}{|c|}{ Yield (\%) } \\
\hline & & & & Recycle1 & Recycle2 & Recycle3 \\
\hline 1 & $1 \mathrm{a}$ & $2 \mathrm{a}$ & $3 a$ & 94 & 90 & 88 \\
\hline 2 & $1 b$ & $2 b$ & $3 b$ & 93 & 91 & 86 \\
\hline 3 & $1 \mathrm{c}$ & $2 c$ & $3 \mathrm{c}$ & 94 & 89 & 85 \\
\hline
\end{tabular}




\section{Experimental Section}

Catalyst preparation. To a solution of $100 \mathrm{gm}$. stannous chloride $\left(\mathrm{SnCl}_{4} \mathrm{nH}_{2} \mathrm{O}\right)$ in $300 \mathrm{ml}$. water $25 \%$ ammonia solution was added drop wise with constant stirring till the $\mathrm{pH}$ of solution was adjusted to 8 . The precipitated product was collected by filtration and poured onto cold solution of ammonium acetate $(500 \mathrm{ml})(0.5$ to $4 \%)$. The precipitated solid was filtered and dried at $100^{\circ} \mathrm{C}$ for $24 \mathrm{~h}$. Tin oxide gel $(2 \mathrm{gm})$ obtained was taken in a glass suction funnel and concentrated sulphuric acid $(30 \mathrm{ml})$ was added slowly to it and the mixture was allowed to stand for 1 hour. The solid obtained was filtered and dried at $100^{\circ} \mathrm{C}$ for $2 \mathrm{~h}$. Then the solid was heated in air at $500^{\circ} \mathrm{C}$ for $3 \mathrm{~h}$ and stored in a sealed sample bottle until use $\mathrm{e}^{15}$.

Synthesis of 2,4-Diphenyl-4,6,7,8-tetrahydrochromen-5-one. To a mixture of 5,5-dimethylcyclohexane-1,3, dione (1 mmol) (1a), 1,3-diphenyl-propenone (2a) (1 mmol) in $10 \mathrm{ml}$. dimethyl formamide (DMF) solvent, $5 \mathrm{~mol} \%$ of catalyst sulfated tin oxide was added. The mixture was stirred at $90^{\circ} \mathrm{C}$ for an appropriate time. Progress of reaction was monitored by TLC. After completion of reaction, the reaction mixture was cooled and filtered to remove insoluble catalyst. The filtrate was added slowly to ice-cold water with constant stirring. The obtained solid (3a) was purified by column chromatography using chloroform and ethyl acetate eluent in the ratio of 3:1. The separated solid super acid was washed with ethyl acetate, $5 \% \mathrm{NaHCO}_{3}$ and finally with cold water and dried at $110{ }^{\circ} \mathrm{C}$ for $1 \mathrm{~h}$ for further reuse. The so-obtained products $(\mathbf{3 a - j})$ were identified by comparison with authentic samples, ${ }^{1} \mathrm{HNMR}$ and their melting points (Table 1).

\section{Conclusions}

In summary we have been demonstrated an efficient and mild protocol for the synthesis of 4,6,7,8-tetrahydro chromen-5-one using sulfated tin oxide (STO) as solid super acid catalyst. The catalyst was used for several times without significance loss of its catalytic properties. The method offers several advantages such as higher yields, shorter reaction times, cleaner reaction profiles and simple experimental and work up procedure.

\section{Acknowledgements}

The authors are thankful to the Principal P. L. More, Dnyanopasak College, Parbhani, for encouragement during the process of carrying out this work. 


\section{References}

1. Brooks, G. T.; Ottridge, A. P.; Mace, D. W. Pestic Sci. 1988, 22, 41.

2. Chand, N.; Diamantis, W.; Sofia, R. D. Brit. J. Pharmacol. 1986, 87, 443.

3. Witte, E. C.; Neubert, P.; Roesch, A. Ger. Offen, DE 3. 427, 985 (to Boehringer Mannheim) 30 Jan 1986; Chem. Abstr. 1986, 104, $224915 f$.

4. Morianka, Y.; Takhashi, K. Japan Kokai, 77, 17, 498 (to Mitsubishi Yuka Yakuhim Co) 9 Feb 1977; Chem. Abstr. 1977, 87, 102299t.

5. Montondon, J. B.; Zijlstra, F. J.; Wilson, J. H. P.; Grand Jean E. M.; Cireurel, L. Int. J. Tissue Reac. 1989, 11, 107.

6. Hyema, T.; Saimoto, H. Japan Kokai Tokkyo Koho, JP 62, 181, 276, 8 Aug 1987; Chem. Abstr. 1988, 108, 37645.

7. Lipinski, C. A. EP, 230, 379 (to Pfizer Inc.), 29 July 1987; Chem. Abstr. 1988, 108, 75224.

8. Ahluwalia, V. K.; Shailaja Rao, J. Indian J. Chem. 1989, $28 B, 81$.

9. Kharchenko, V. G.; Markova, L. I.; Smirnova, N. S.; Korshunova, K. M.; Rybina, G. I. Zhurnal Organicheskoi Khimii 1982, 18, 2184.

10. Ahluwalia, V. K.; Kiran, S.; Aggrwal, R.; Arora, K. K. Indian J. Chem. 1991, 30B, 1095.

11. Rao, A. S.; Mitra, R. B. Indian J. Chem. 1974, 12, 1028.

12. Ahmed, M.G.; Ahmed, S. A.; Romman, U. K. R.; Sultana, T.; Hena, M. A.; Kiyooka, S. Indian J. Chem. 2002, $41 B, 368$.

13. (a) Ahmed, M. G.; Ahmed, S. A.; Romman, U. K. R.; Sultana, T.; Rahman, M. B.; Hossain, M. A.; Khabir Uddin, Md.. Indian J. Chem. 2005, 44, 622. (b) Ahmed, M. G.; Ahmed, S. A.; Bahar, M. H.; Khondaker, M. A.; Islam, A. K.; Anam, M. M. Indian J. Chem. 1982, 21, 470.

14. (a) Hino, M.; Atata, K. J. Chem. Soc., Chem. Commun. 1980 851. (b) Igiesia, E.; Sale, S. L.; Kramer, G. M. J. Catal, 1993, 144, 238.

15. (a) Hisomi Matsuhshi, Hideneri Miyazaki, Kazushi Arata, Chem. Lett. 2001, 442, 483. (b) Holm, X. C. F.; Bailey, G. C.; U. S. Patent, 3,032, 599, 1962. (c) Yori, J. C.; D Amato M. A; Costa G; Perera J. M. J. Catal. 1995,153, 218.

16. Gutierrez-Baez, R.; Toledo-Antonio, J. A.; Cortes-Jacome, M. A.; Sebastian, P. J.; Vazuer, A. Langmuir 2004, 20, 4265.

17. Arata K.; Matsuhashi, H.; Hino M.; Nakamura, H. Catal. Today 2003, 81, 17.

18. Cotton, F. A ; Wilkinson, G. Advanced Inorganic Chemistry $5^{\text {th }}$ Edn.; Wiley: New York, $1988 ;$ p924.

19. Chiu-Hsun, Lin.; Shawn, D.; Lin, Yi-Hung Yang; Tsung, Po Lin. Catal. Lett. 2001, 23, 24.

20. Nicholas, C. P.; Marks, T. J. Nano Letters 2004, 4, 1557. 